\title{
Defluoridation by Al-based coagulation and adsorption: Species transformation of aluminum and fluoride
}

\author{
Zan $\mathrm{He}^{\mathrm{a}, \mathrm{b}}$, Ruiping Liu ${ }^{\mathrm{a}, *}$, Jin $\mathrm{Xu}^{\mathrm{a}}$, Huijuan Liu ${ }^{\mathrm{a}}$, Jiuhui $\mathrm{Qu}^{\mathrm{a}}$ \\ ${ }^{a}$ Key Laboratory of Drinking Water Science and Technology, Research Center for Eco-Environmental Science, Chinese Academy of Sciences, Beijing 100085, China \\ ${ }^{\mathrm{b}}$ University of Chinese Academy of Sciences, Beijing 100039, China
}

\section{A R T I C L E I N F O}

\section{Article history:}

Received 10 December 2014

Received in revised form 27 April 2015

Accepted 8 May 2015

Available online 13 May 2015

\section{Keywords:}

Fluoride

Al coagulation

AlOxHy adsorption

Al-F complexes

Fluoride dissolution effect

\begin{abstract}
A B S T R A C T
The species transformation of $\mathrm{Al}$ and fluoride in fluoride removal by Al-based coagulation and adsorption is far from being well-characterized. This study used batch- and pilot-scale experiments to compare the fluoride removal efficiency and species transformation of $\mathrm{Al}$ and fluoride in $\mathrm{Al}$ coagulation with that in $\mathrm{Al}$ precipitate (AlOxHy) adsorption. Al coagulation showed superior removal of fluoride compared to AlOxHy adsorption. In the coagulation process, the formation of complexed fluoride (Com-F) occurred, and Com-F concentrations increased with elevated $\mathrm{Al}$ dose, i.e., lowered $\mathrm{pH}$. At initial $\mathrm{pH}$ of 8.6 , free fluoride (Free-F) dominated in the adsorption system even at the high AlOxHy dose of $200 \mathrm{mg} \mathrm{Al} / \mathrm{L}$ whereas at $\mathrm{pH}<7.0, \mathrm{Com}-\mathrm{F}$ was the dominant species in both systems. Fluoride had an influence on $\mathrm{Al}^{3+}$ hydrolysis and favored the transformation of $\mathrm{Al}^{3+}$ and $\mathrm{Al}-\mathrm{F}$ complexes to $\mathrm{Al}-\mathrm{F}$ precipitates, and the removal of fluoride by coagulation was improved thereafter. Fluoride also promoted the dissolution of AlOxHy, the extent of which was more significant at lowered $\mathrm{pH}$ from 7.0 to 4.0 and at elevated ratios of fluoride to $\mathrm{Al}$ from 0.15 to 2.45 . The formation of Al-F complexes impaired fluoride removal by adsorption. A pilot-scale field study also indicated that coagulation showed higher efficiency than adsorption in the removal of fluoride. The average ratios of Com-F to total fluoride were 0.14:1 and 0.04:1, respectively, in coagulation and adsorption processes.
\end{abstract}

(C) 2015 Elsevier B.V. All rights reserved.

\section{Introduction}

Excessive exposure to fluoride via drinking water has aroused wide concern due to the widespread occurrence of dental and skeletal fluorosis. Many technologies to remove fluoride from groundwater and industrial wastewater such as (electro)coagulation, adsorption, ion exchange, precipitation, and membrane separation have been well studied [1-6]. Coagulation and adsorption are highly efficient and cost-effective, and require less maintenance and show higher water production ratios than other processes. From an engineering point-of-view, they are therefore more feasible and available in underdeveloped rural areas.

Aluminum (Al) salts are most widely used for coagulation, and the removal of fluoride is mainly achieved by adsorption, charge neutralization and enmeshment, complex precipitation, and electronic attraction, etc. [7]. However, the dominant mechanism may be highly dependent on the operation procedures. In cases where $\mathrm{Al}$ ion $\left(\mathrm{Al}^{3+}\right)$ and base solutions are simultaneously dosed, the adsorption of fluoride onto $\mathrm{Al}(\mathrm{OH})_{3}$ precipitates dominates in

\footnotetext{
* Corresponding author. Tel.: +86 10 62849128; fax: +86 1062849160 .

E-mail address: liuruiping@rcees.ac.cn (R. Liu).
}

fluoride removal $[7,8]$. When $\mathrm{Al}^{3+}$ solution is dosed prior to adding base solution, the formation of aluminum fluoride complexes (Al-F complexes) occurs prior to $\mathrm{Al}^{3+}$ hydrolysis. Al-F complexes may directly transform to $\mathrm{Al}-\mathrm{F}-\mathrm{OH}$ precipitates and achieve the removal of fluoride [1]. The participation of fluoride in precipitate formation may differ greatly from its direct adsorption onto $\mathrm{Al}(\mathrm{OH})_{3}$ precipitate. However, few studies have carefully illustrated the different removal behaviors toward fluoride or the mechanisms involved in these two procedures. Our previous study indicated that the formation of $\mathrm{Al}-\mathrm{F}$ complexes is more significant at lower $\mathrm{pH}$ and higher ratios of fluoride to $\mathrm{Al}\left(\mathrm{R}_{\mathrm{F}: \mathrm{Al}}\right)$ [9]. The removal of fluoride by (electro) coagulation has been observed to be strongly dependent on $\mathrm{Al}$ dose, $\mathrm{pH}, \mathrm{Al}$ species, and $\mathrm{R}_{\mathrm{F}: \mathrm{Al}}$ [1,10-12]. Generally, the addition of $\mathrm{Al}^{3+}$ contributes to the decrease of $\mathrm{pH}$ owing to $\mathrm{Al}^{3+}$ hydrolysis, and this effect could affect the species distribution of $\mathrm{Al}$ and fluoride, and subsequently fluoride removal is sensitive to the above factors. The Al-F complexes play important roles in promoting fluoride removal to a large extent [9]. Additionally, these complexes may also have an influence on Al hydrolysis and the species distribution and transformation of $\mathrm{Al}$ and fluoride. 
Activated alumina is one of the best adsorbents for fluoride removal and has been widely used in practice [13]. However, its application is restricted by its relatively low adsorption capacity, i.e., equilibrium adsorption capability of $2-4 \mathrm{mg} / \mathrm{g}$, as well as the complicated regeneration procedures required. The granulation of conventional adsorbents is achieved at the expense of significantly lowered adsorption capacity. To overcome these drawbacks, we successfully developed a novel adsorbent by coating ferric and manganese binary oxide (FMBO) onto diatomite in-situ [14]. The freshly-prepared aluminum hydroxide, i.e., in-situ $\mathrm{Al}_{2} \mathrm{O}_{3} \cdot x \mathrm{H}_{2} \mathrm{O}$, as briefly expressed by AlOxHy, shows maximum adsorption capacity higher than $110 \mathrm{mg} \mathrm{F} / \mathrm{g} \mathrm{Al}$, and exhibits superior performance compared to other conventional adsorbents such as activated alumina, nano-scale aluminum oxide hydroxide, and $\mathrm{Zr}-\mathrm{Mn}$ composite material [15-17]. The in-situ coating method may be also applicable in the preparation of a defluoridation adsorbent. Additionally, alumina with different acidity-alkalinity can be prepared through controlling the surface density of hydroxyl groups [18], and it indicates that alumina is an amphoteric oxide. Therefore, AlOxHy tends to dissolve into soluble $\mathrm{Al}$ in acidic and basic $\mathrm{pH}$ ranges, although the extent is relatively slight [19]. The presence of fluoride complicates the situation for AlOxHy dissolution considering that free fluoride tends to form $\mathrm{Al}-\mathrm{F}$ complexes with the dissolved $\mathrm{Al}^{3+}$ at low $\mathrm{pH}$. However, few studies have evaluated the effect of fluoride on AlOxHy dissolution and the removal of fluoride thereafter.

This study used groundwater collected from the suburb of Langfang City, Hebei Province in China, with fluoride concentrations of 3.3-4.4 mg/L, and aimed to: (1) compare the two processes of $\mathrm{Al}^{3+}$ coagulation and $\mathrm{AlOxHy}$ adsorption with respect to fluoride removal and fluoride species transformation as a function of $\mathrm{Al}$ dose and $\mathrm{pH}$; (2) determine the effect of fluoride at different $\mathrm{R}_{\mathrm{F}: \mathrm{Al}}$ on $\mathrm{Al}^{3+}$ hydrolysis and the dissolution and fluoride removal of AlOxHy over a wide $\mathrm{pH}$ range; (3) propose the dominant pathways involved in the species transformation of fluoride and $\mathrm{Al}$ at different $\mathrm{pH}$ and $\mathrm{R}_{\mathrm{F}: \mathrm{Al}}$; and (4) evaluate the fluoride removal behavior and species transformation for these two processes in a continuous pilot-scale system.

\section{Materials and methods}

\subsection{Chemicals and materials}

Unless specifically noted, all chemicals used in the experiments were analytical grade and were used without further purification. The stock solutions of $\mathrm{Al}^{3+}(4 \mathrm{~g} / \mathrm{L})$ and fluoride $(13 \mathrm{~g} / \mathrm{L})$ were respectively prepared by dissolving aluminum sulfate $\left[\mathrm{Al}_{2}\left(\mathrm{SO}_{4}\right)_{3} \cdot 18 \mathrm{H}_{2} \mathrm{O}\right]$ and sodium fluoride $(\mathrm{NaF})$ in deionized water. $\mathrm{pH}$ adjustment was accomplished using $1 \mathrm{M}$ hydrochloric acid $(\mathrm{HCl})$ and sodium hydroxide $(\mathrm{NaOH})$.

The groundwater, collected from the suburb of Langfang City, Hebei Province, was employed in both the laboratory and pilot-scale studies, and the fluoride concentration was determined to range from 3.3 to $4.4 \mathrm{mg} / \mathrm{L}$. The main characteristics of the groundwater are illustrated in Table S1. Water containing higher fluoride concentrations used in study than raw water was prepared by adding appropriate amounts of the fluoride stock solution to raw water.

\subsection{Experimental methods}

\subsubsection{Batch tests}

2.2.1.1. Coagulation test. Coagulation tests were conducted using a Phipps and Bird six-paddle stirrer (MY 3000-6, QianJiangMeiYu Instruments, China) at room temperature. Raw water at $300 \mathrm{~mL}$ was transferred to a $500-\mathrm{mL}$ beaker, and Al stock solution was added to obtain an $\mathrm{Al}$ dose of $40 \mathrm{mg} / \mathrm{L}$. The procedures used were as follows: 2-min mixing at $100 \mathrm{rpm}$ for $\mathrm{pH}$ adjustment to desired $\mathrm{pH}$ values, 2-min rapid mixing at $200 \mathrm{rpm}, 15$-min slow mix at $40 \mathrm{rpm}$, and 30-min settling period. After that, the final coagulation $\mathrm{pH}$ was measured and the supernatant at $2-\mathrm{cm}$ below the water level was collected and filtered through a $0.45-\mu \mathrm{m}$ membrane filter. The filtrates were carefully kept air-tight at $4{ }^{\circ} \mathrm{C}$ for further analysis of the concentrations of fluoride and $\mathrm{Al}$.

2.2.1.2. Adsorption tests. Adsorption tests followed the abovementioned procedures except that the AlOxHy was used. AlOxHy was prepared by the method described in our previous study [19], i.e., reaction between $\mathrm{Al}_{2}\left(\mathrm{SO}_{4}\right)_{3}$ and $\mathrm{NaOH}$ at equivalent molar ratio of $1: 3$. AlOxHy was dosed into the $300-\mathrm{mL}$ raw water immediately after being prepared. While investigating the removal behavior of AlOxHy toward fluoride at elevated fluoride concentrations, the fluoride stock solution was added to obtain the desired fluoride concentrations of $16.3,31.6,52.7$, and $69.0 \mathrm{mg} / \mathrm{L}$.

2.2.1.3. Titration experiments on $\mathrm{Al}^{3+}$ hydrolysis. A mixed liquor of $\mathrm{Al}$ and fluoride solution was prepared in a $1 \mathrm{~L}$ Plexiglass beaker. With stirring at $300 \mathrm{rpm}, 1 \mathrm{M} \mathrm{NaOH}$ was continually added to the mixed liquor by a $100-\mu \mathrm{L}$ microsyringe. The volume of base and $\mathrm{pH}$ were recorded and plotted. The process of titration was ended at pH 9.0. To avoid dissolution of carbon dioxide in the mixture, nitrogen was continuously purged. The dose of $\mathrm{Al}$ was $40 \mathrm{mg} / \mathrm{L}$ with fluoride concentrations of $4.4,16.3$, and $31.6 \mathrm{mg} / \mathrm{L}$.

\subsubsection{Pilot-scale field test}

The pilot-scale field study was carried out in a village located in the suburb of Langfang City, and the groundwater was directly used as raw water without any pretreatment. The pilot-scale system with a designed treatment scale of $0.5 \mathrm{~m}^{3} / \mathrm{h}$ included one raw water tank, one adsorption reactor with internal diameter of $700 \mathrm{~mm}$ and height of $1600 \mathrm{~mm}\left(\mathrm{R}_{\mathrm{Ads}}\right)$, one reactor with two combined subunits for coagulation and sedimentation $\left(\mathrm{R}_{\mathrm{Coag}+\mathrm{Sed}}\right)$, and one sand filter with quartz sand as the filter medium (Fig. 1). The designed upflow velocity in $\mathrm{R}_{\mathrm{Ads}}$ was $1.3 \mathrm{~m} / \mathrm{h}$ with an empty bed contact time $(E B C T)$ of $60 \mathrm{~min}$. As for $\mathrm{R}_{\mathrm{Coag}+\mathrm{Sed}}$, the designed hydraulic retention times were 15 and 120 min for the 3-stage coagulation and sedimentation subunits, respectively. The height of the filter bed was $1000 \mathrm{~mm}$ and the diameter of the quartz sand was in the range $0.5-1 \mathrm{~mm}$. The $R_{\text {Ads }}$ and $R_{\text {Coag+Sed }}$ units were able to be separately operated, and the effluents of both units flowed into the sand filter, at the filtration velocity of $6.5 \mathrm{~m} / \mathrm{h}$, for the removal of suspended particles.

While investigating the fluoride removal efficiency of coagulation, an $\mathrm{Al}_{2}\left(\mathrm{SO}_{4}\right)_{3} \cdot 18 \mathrm{H}_{2} \mathrm{O}$ (Industrial Grade) stock solution at

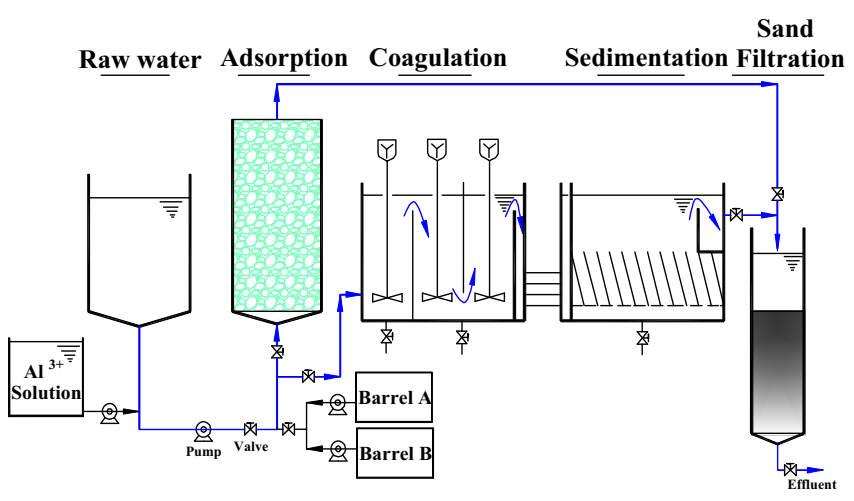

Fig. 1. The schematic set-up of pilot-scale coagulation and adsorption processes 
9.6 $\mathrm{g} / \mathrm{L}$ as Al was continuously dosed by a metering pump to obtain the designed dose of $35 \mathrm{mg} / \mathrm{L}$ as Al. The dosing-point of the $\mathrm{Al}_{2}\left(\mathrm{SO}_{4}\right)_{3}$ solution was prior to the elevation pump and was well agitated with the raw water therein. After flowing through the $\mathrm{R}_{\mathrm{Coag}+\mathrm{Sed}}$ and sand filter, the effluent was sampled to analyze equilibrium $\mathrm{pH}$ and the residual concentrations of total $\mathrm{Al}$, total fluoride $\left([\mathrm{F}]_{\text {total }}\right)$, and complexed fluoride (Com-F).

While investigating the fluoride removal efficiency of adsorption, raw water was pumped and flowed through the adsorption and filtration units in sequence. To adjust $\mathrm{pH}$, a stock solution of nitric acid $(0.27 \mathrm{~g} / \mathrm{L})$ was continuously dosed by a metering pump at designed flow rates of $73,104,135$, and $166 \mathrm{~mL} / \mathrm{min}$ to obtain desired pHs near 6.90, 6.70, 6.50, and 6.30. The nitric acid solution was also agitated in the elevation pump. The AlOxHy was loaded into the adsorption reaction by the method developed in our previous study [14]. The filter effluents were also sampled at intervals for further analysis.

\subsection{Analytical methods}

$\mathrm{pH}$ was measured with a high precision $\mathrm{pH}$ meter (Orion $720 \mathrm{~A}$, U.S.A.). $[\mathrm{F}]_{\text {total }}$ was determined using a fluoride ion selective electrode (PF-1, Kangyi instrument Ltd., China). The concentrations of free fluoride (Free-F) were determined by the method indicated in our previous study [9], and the Com-F concentrations were calculated by subtracting Free-F from $[\mathrm{F}]_{\text {total }}$.

Residual Al concentrations were determined by Inductively Coupled Plasma Atomic Emission Spectroscopy (ICP-OES) (SCIEX Perkin-Elmer Elan mode 5000).

Zeta potential was measured by a zeta potential analyzer (Zetasizer 2000, Malvern, UK). At least 3 runs were used for each of the measurements, and the average data are presented. Solid-state ${ }^{27} \mathrm{Al}$ nuclear magnetic resonance (NMR) spectroscopy was performed by a Varian UNITYINOVA (500 MHz) spectrometer to determine the Al species within the obtained precipitates after batch experiments employing these two processes. Details of the operating approach and parameters of the apparatus can be found in the literature [20].

\subsection{Modeling methods}

Visual MINTEQ Version 3.0 software was used to calculate the content of different fluoride species and complexed $\mathrm{Al}$ (Com-Al). The different species included were as follows: $\mathrm{Al}^{3+}, \mathrm{F}^{-}, \mathrm{Al}(\mathrm{OH})^{2+}$, $\mathrm{Al}(\mathrm{OH})_{4}^{-}, \mathrm{AlF}^{2+}, \mathrm{AlF}_{2}^{+}, \mathrm{AlF}_{3}(\mathrm{aq}), \mathrm{AlOH}^{2+}, \mathrm{HF}_{(\mathrm{aq})}, \mathrm{HF}_{2}^{-}, \mathrm{AlF}_{4}^{-}$, and $\mathrm{Al}_{2}(\mathrm{OH})_{2}^{4+}$, and the four Al-F complexes of $\mathrm{AlF}^{2-}, \mathrm{AlF}_{2}^{-}, \mathrm{AlF}_{3}$, and $\mathrm{AlF}_{4}^{-}$were related to the Com-F and Com-Al.

\section{Results and discussion}

\subsection{Removal of fluoride by coagulation and adsorption}

\subsubsection{Effects of Al dose on species transformation and removal of fluoride}

The variation of residual fluoride in terms of total fluoride (Total-F), Free-F, and Com-F with elevated Al dose is illustrated in Fig. 2. Al coagulation contributed to steady decrease of $[\mathrm{F}]_{\text {total }}$ from 3.71 to $0.56 \mathrm{mg} / \mathrm{L}$ with the increase of $\mathrm{Al}$ dose from 0 to $50 \mathrm{mg} / \mathrm{L}$. Further increase of Al dose adversely affected the removal of fluoride, and $[\mathrm{F}]_{\text {total }}$ increased to as high as $2.46 \mathrm{mg} / \mathrm{L}$ at the elevated $\mathrm{Al}$ dose of $70 \mathrm{mg} / \mathrm{L}$. Additionally, it was observed that elevated $\mathrm{Al}$ doses from 20 to $50 \mathrm{mg} / \mathrm{L}$ increased the zeta potential of Al flocs from +5.1 to $+18.1 \mathrm{mV}$, and with further elevation of $\mathrm{Al}$ dose to $70 \mathrm{mg} / \mathrm{L}$, the zeta potential slightly decreased to $+13.2 \mathrm{mV}$. The variation trends of zeta potential corresponded well

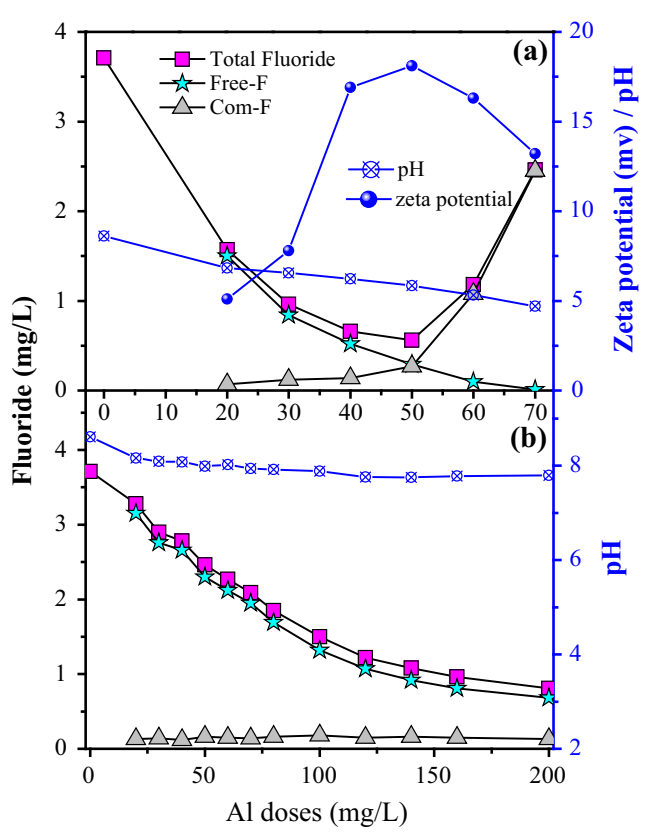

Fig. 2. The concentration of residual fluoride and solution $\mathrm{pH}$ after coagulation (a) and adsorption (b) at different doses of $\mathrm{Al}$ (Experimental conditions: $[\mathrm{F}]_{0}=3.71$ $\mathrm{mg} / \mathrm{L})$.

to the removal of fluoride by Al coagulation, and this indicated that the surface charge of Al flocs had a significant effect on the removal of negatively-charged fluoride. The equilibrium $\mathrm{pH}$ continuously decreased from 8.6 to 4.7 with steady increase of Al dose from 0 to $70 \mathrm{mg} / \mathrm{L}$. This was attributed to the hydrolysis of $\mathrm{Al}^{3+}$ and the consumption of $\mathrm{OH}^{-}$, which was more significant at elevated $\mathrm{Al}$ doses. At $\mathrm{Al}$ doses of above $40 \mathrm{mg} / \mathrm{L}$ the equilibrium $\mathrm{pH}$ decreased to below 6.5, and the formation of Al-F complexes occurred. Generally, the formation of Com-F occurs under weakly acidic and acidic conditions [9]. With Al dose increasing from 20 to $70 \mathrm{mg} / \mathrm{L}$ the concentration of Com-F increased remarkably from 0.07 to $2.45 \mathrm{mg} / \mathrm{L}$, whereas that of Free-F decreased accordingly. The elevated $[\mathrm{F}]_{\text {total }}$ at excessive Al dose was attributed to the formation of soluble Al-F complexes, and at Al doses of above $60 \mathrm{mg} / \mathrm{L}$ little difference could be observed between the concentrations of Com-F and Total-F. Additionally, the dissolution of Al-based precipitates occurred at lowered pH (Fig. S1a), and this effect decreased the amount of $\mathrm{Al}$ precipitates available and inhibited fluoride removal. The maximum removal of fluoride by Al coagulation was achieved at the optimum $\mathrm{Al}$ dose of $30 \mathrm{mg} / \mathrm{L}$.

By using the visual MINTEQ software, the ratios of different Com-F species to total Com-F were further quantified for the residual fluoride after $\mathrm{Al}$ coagulation over a wide $\mathrm{Al}$ dose range from 20 to $70 \mathrm{mg} / \mathrm{L}$ (Fig. S2), and four Al-F complexes, i.e., $\mathrm{AlF}^{2+}, \mathrm{AlF}_{2}^{+}, \mathrm{AlF}_{3}$ and $\mathrm{AlF}_{4}^{-}$, were included. These four Com-F species showed different variation trends with elevated $\mathrm{Al}$ dose. The ratio of $\mathrm{AlF}_{3}$ decreased from $53.6 \%$ at $\mathrm{Al}$ dose of $20 \mathrm{mg} / \mathrm{L}$ to $39.9 \%, 22.1 \%$, and $4.4 \%$ at $\mathrm{Al}$ doses of 30,40 , and $50 \mathrm{mg} / \mathrm{L}$, respectively. $\mathrm{AlF}_{2}^{+}$was the dominant Com-F species in the Al doses range from 20 to $60 \mathrm{mg} / \mathrm{L}$, and the ratios of $\mathrm{AlF}_{2}^{+}$were in the range from $41.6 \%$ to $72.6 \%$ accordingly. At elevated $\mathrm{Al}$ doses of 60 and $70 \mathrm{mg} / \mathrm{L}, \mathrm{AlF}^{2+}$ was the dominant species and accounted for $57.7 \%$ and $86.5 \%$ of total Com-F. The ratio of $\mathrm{AlF}_{4}^{-}$was below $2.6 \%$ over a wide $\mathrm{Al}$ dose range from 20 to $70 \mathrm{mg} / \mathrm{L}$. Additionally, it was indicated that the formation of $\mathrm{AlF}_{3}$ was benefited at low $\mathrm{Al}$ doses, whereas that of $\mathrm{AlF}^{2+}$ was favored at high $\mathrm{Al}$ doses. The ratios of different Com- $\mathrm{F}$ species were dependent on $\mathrm{pH}$ and $\mathrm{R}_{\mathrm{F}: \mathrm{Al}}$. 
As shown in Fig. 2b, the removal of fluoride by its adsorption onto AlOxHy showed critically different trends from that by $\mathrm{Al}$ coagulation. $[\mathrm{F}]_{\text {total }}$ gradually decreased from 3.71 to $0.81 \mathrm{mg} / \mathrm{L}$ at $200 \mathrm{mg} / \mathrm{L}$ of AlOxHy dose as $\mathrm{Al}$, and equilibrium $\mathrm{pH}$ decreased slightly from 8.6 to 7.8 accordingly. The removal of fluoride by adsorption was attributed to the removal of Free-F, which decreased from 3.01 to $0.68 \mathrm{mg} / \mathrm{L}$ and showed a trend similar to that of $[\mathrm{F}]_{\text {total }}$. Comparatively, the levels of Com-F were consistently below $0.16 \mathrm{mg} / \mathrm{L}$, and it was inferred that the formation of $\mathrm{Al}-\mathrm{F}$ complexes was slight in this system. Moreover, the dissolution of Al-based precipitates showed little variation over a wide Al dose range and occurred to a remarkably lower extent than in the coagulation system (Fig. S1b). To achieve the maximum contaminant level (MCL) of fluoride $(<1 \mathrm{mg} / \mathrm{L})$ in the drinking water standard, the optimum Al doses were determined to be 30 and $160 \mathrm{mg} / \mathrm{L}$ for coagulation and adsorption, respectively.

\subsubsection{Effects of $\mathrm{pH}$ on species transformation and removal of fluoride}

Fig. 3 compares the species distribution of fluoride between the coagulation and adsorption systems over a wide $\mathrm{pH}$ range from 4 to 9 , at the $\mathrm{Al}$ dose of $40 \mathrm{mg} / \mathrm{L}$. In both processes the removal of Total-F was most significant in weakly acidic and neutral $\mathrm{pH}$ of 6 and 7. In the coagulation system, complexation between $\mathrm{Al}$ and fluoride occurs at pH below 7 [9], and Al-F complexes consume less $\mathrm{OH}^{-}$to transform into $\mathrm{Al}-\mathrm{F}-\mathrm{OH}$ coprecipitates compared to precipitate formation for $\mathrm{Al}^{3+}$ at weakly acidic and neutral $\mathrm{pH}$ of 6 and 7 . Additionally, the removal efficiency of fluoride was observed to be positively correlated with zeta potential, and the maximum zeta potential of the Al-based coagulant and adsorbent were determined to be +22.0 and $+17.5 \mathrm{mV}$ at $\mathrm{pH} 6.0$ for adsorption and coagulation systems. Zeta potential analysis indicated that the Al flocs and AlOxHy exhibited positive surface charge over $\mathrm{pH} 4-9$, and the adsorption of negatively charged fluoride was favored accordingly. Additionally, $\mathrm{Al}$ (hydro)oxide exhibits amphoteric character and its transformation in different $\mathrm{pH}$ ranges may be described by Eqs. (1) and (2). At low pH the removal of fluoride was inhibited by the insufficient hydrolysis of $\mathrm{Al}$ ions (Eq. (1)) whereas at high $\mathrm{pH}$, the formation of aluminates (Eq. (2)) adversely affected fluoride removal.

$\mathrm{Al}^{3+}+n \mathrm{OH}^{-}=\mathrm{Al}(\mathrm{OH})_{n}^{(3-n)-}(n=1,2,3)$

$\mathrm{Al}(\mathrm{OH})_{3}+\mathrm{OH}^{-}=\mathrm{Al}(\mathrm{OH})_{4}^{-}$

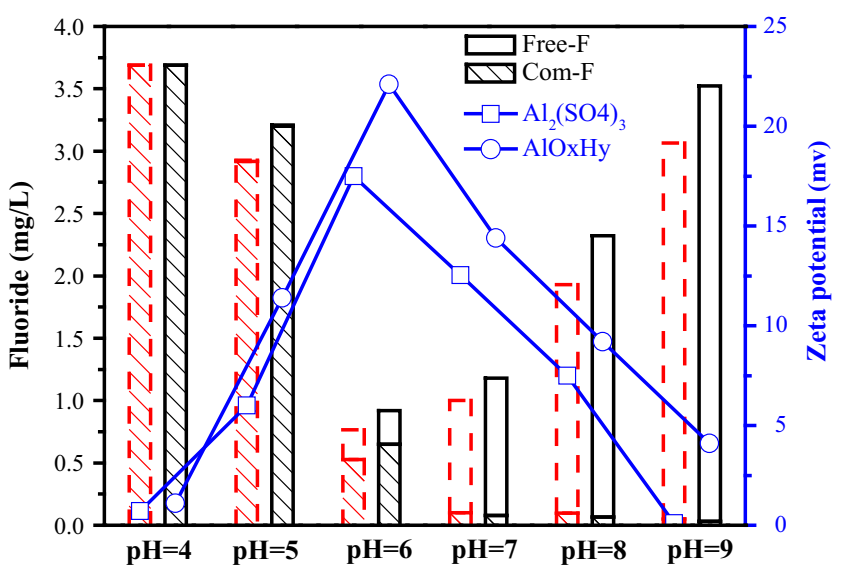

Fig. 3. Fluoride species distribution at different $\mathrm{pH}$ after coagulation and adsorption, and coagulation and adsorption were shown as dotted line and solid line of bar graph, respectively. (Experimental conditions: $[\mathrm{F}]_{0}=4.44 \mathrm{mg} / \mathrm{L}, \mathrm{Al}$ doses $=40 \mathrm{mg} / \mathrm{L}$, $[\mathrm{F}]_{\text {total }}=[\mathrm{F}]_{\text {Free-F }}+[\mathrm{F}]_{\text {Com-F }}$ )
Additionally, it was observed that Com-F was dominant at $\mathrm{pH}<7$ in both systems, and Free-F could hardly be detected at $\mathrm{pH} 4$ and 5. The concentrations of Com-F, Free-F, and Total-F were determined to be $2.92,0.01,2.93 \mathrm{mg} / \mathrm{L}$ at $\mathrm{pH} 5.0$ and to be 0.53 , $0.24,0.77 \mathrm{mg} / \mathrm{L}$ at $\mathrm{pH} 6.0$, respectively. At elevated $\mathrm{pH}$ above 7 , Free-F was the dominant fluoride species and contributed most to Total-F, and these two fluoride species showed similar variation trends accordingly. Quantitatively, the concentrations of Free-F increased from 0.24 to $3.02 \mathrm{mg} / \mathrm{L}$ whereas those of Total-F increased from 0.76 to $3.07 \mathrm{mg} / \mathrm{L}$ as $\mathrm{pH}$ increased from 6.0 to 9.0. At elevated $\mathrm{pH}, \mathrm{OH}^{-}$at higher concentrations showed more significant competitive effects toward $\mathrm{Al}$ ions than fluoride did [9], and contributed to the dissociation of Com-F to Free-F thereafter.

In both systems the extent of Com-F dissociation increased with elevated $\mathrm{pH}$, and the Com-F not only dissociated into Free-F but also directly transformed to insoluble $\mathrm{Al}-\mathrm{F}-\mathrm{OH}$ precipitates. The dominant products were observed to be highly dependent the $\mathrm{pH}$ range. With $\mathrm{pH}$ increasing from 4 to 5 , the Com- $\mathrm{F}$ mainly transformed into insoluble fluoride and the formation of Free-F was slight. At elevated pH from 5 to 6 the transformation of these two fluoride species occurred, and significant removal of Total-F was achieved by the formation of $\mathrm{Al}-\mathrm{F}-\mathrm{OH}$ precipitates. In contrast, the increase of $\mathrm{pH}$ from 6 to 7 mainly contributed to the transformation of Com-F to Free-F. The further increase of $\mathrm{pH}$ to above 7 was conducive to the dissolution of insoluble fluoride to Free-F. Coagulation showed better efficiency than adsorption with respect to the removal of Total-F over wide $\mathrm{pH}$ ranges from 5 to 9 , and the formation of Com-F was inferred to benefit fluoride removal over wide $\mathrm{pH}$ ranges. Interestingly, it was observed that Com-F did exist in the adsorption system, especially under acidic $\mathrm{pH}$ conditions. At acidic $\mathrm{pH}$ the dissolution of AlOxHy into $\mathrm{Al}$ ions such as $\mathrm{Al}^{3+}$ and $\mathrm{AlOH}^{2+}$ occurred [21], and this contributed to the formation of $\mathrm{Al}-\mathrm{F}$ complexes thereafter. The dominant reactions between $\mathrm{Al}$ and fluoride taking place in these two systems were different, and this contributed to their different removal efficiencies toward fluoride. Interestingly, the formed precipitates in coagulation and adsorption systems showed little difference in terms of aluminum species, as indicated by solid-state ${ }^{27} \mathrm{Al} \mathrm{NMR}$ analysis (Fig. S3). Specifically, after the removal of fluoride by coagulation and adsorption at $\mathrm{pH}$ of $5,6,7$, and 9 , all of these precipitates showed a single peak at $0 \mathrm{ppm}$, which was assigned to octahedrally coordinated $\mathrm{Al}[22]$.

The exact species of Al-F complexes cannot be directly quantified by chemical analysis, and the visual MINTEQ software was

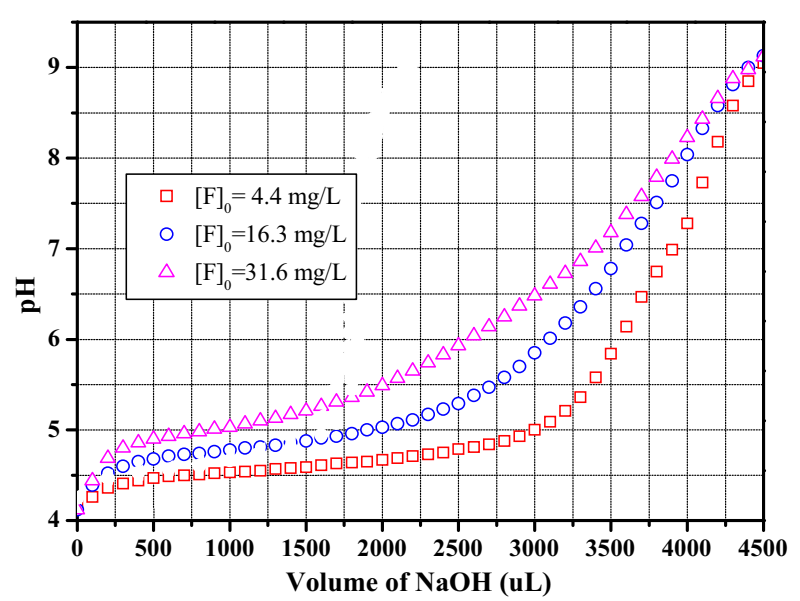

Fig. 4. Titration curve of $\mathrm{Al}^{3+}$ (dose of $\mathrm{Al}=40 \mathrm{mg} / \mathrm{L}$ ) by $1 \mathrm{~mol} / \mathrm{L} \mathrm{NaOH}$ at different fluoride concentrations. 


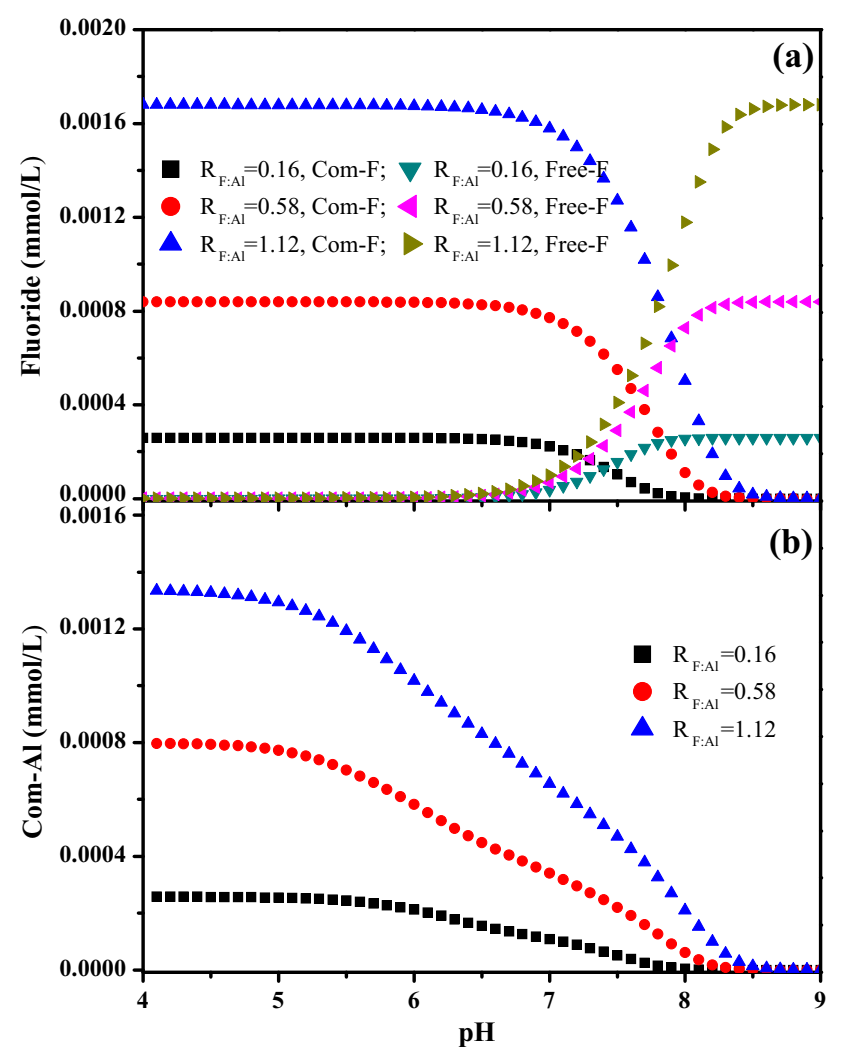

Fig. 5. The concentration of Com-F, Free-F (a) and Com-Al (b) over wide pH ranges from 4.0 to 9.0. (Experimental conditions: dose of $\mathrm{Al}=40 \mathrm{mg} / \mathrm{L},[\mathrm{F}]_{0}=4.4,16.3$ and $31.6 \mathrm{mg} / \mathrm{L})$.

used to provide more information on the complex interactions between $\mathrm{Al}$ and fluoride. Fig. S4 illustrates the ratios of four $\mathrm{Al}-\mathrm{F}$ complexes (i.e., $\mathrm{AlF}^{2+}, \mathrm{AlF}_{2}^{+}, \mathrm{AlF}_{3}$ and $\mathrm{AlF}_{4}^{-}$) to total Com-F in the $\mathrm{pH}$ range from 4 to 6 . In the coagulation system, the ratio of Total-F to total soluble $\mathrm{Al}$ ( $\left.\mathrm{R}_{\text {Tot-F:Tot-Al }}\right)$ increased from $0.15: 1$ at $\mathrm{pH} 4$ to 3.66:1 at pH 6 and the ratio of Com-Al (i.e., $\mathrm{AlF}^{2+}, \mathrm{AlF}_{2}^{+}$, $\mathrm{AlF}_{3}$ and $\left.\mathrm{AlF}_{4}^{-}\right)$to total soluble $\mathrm{Al}\left(\mathrm{R}_{\mathrm{Com}-\mathrm{Al} \text { :Tot-Al }}\right)$ increased from 0.14:1 to $0.72: 1$ accordingly. Additionally, the ratio of $\mathrm{AlF}^{2+}$ to total Com-F decreased from 0.98:1 at pH 4 to $0.81: 1$ at pH 5 and $0.15: 1$ at $\mathrm{pH}$ 6, whereas the ratio of $\mathrm{AlF}_{2}^{+}$to total Com-F increased from 0.02:1 to $0.19: 1$ and $0.77: 1$ accordingly. The transformation of $\mathrm{AlF}^{2+}$ to the Al-F complexes with higher $\mathrm{R}_{\mathrm{F}: \mathrm{Al}}$, i.e., $\mathrm{AlF}_{2}^{+}$and $\mathrm{AlF}_{3}$, was benefited at elevated $\mathrm{pH}$ and $\mathrm{R}_{\text {Tot-F:Tot-Al }}$ (Fig. 4Sa). This may be attributed to the fact that $\mathrm{AlF}_{2}^{+}$consumes less $\mathrm{OH}^{-}$than $\mathrm{AlF}^{2+}$ to form insoluble $\mathrm{Al}-\mathrm{F}-\mathrm{OH}$ precipitates. On the other hand, elevated $\mathrm{R}_{\text {Com-Al:Tot-Al }}$ also benefits the transformation of soluble $\mathrm{Al}$ and fluoride to insoluble $\mathrm{Al}-\mathrm{F}-\mathrm{OH}$ precipitates (Fig. $4 \mathrm{Sb}$ ). The increased removal of fluoride with elevated $\mathrm{pH}$ from 4 to 6 , as observed in Fig. 3, was in good accordance with the increased $\mathrm{R}_{\text {Com-Al:Tot-Al }}$ and the ratio of $\mathrm{AlF}_{2}^{+}$to total Com-F.

Similar trends in terms of the species transformation of fluoride with elevated $\mathrm{pH}$ were also observed in the adsorption system (Fig. S5). However, the pathway to form Al-F complexes is critically different between the coagulation and adsorption processes. In the coagulation system, Al-F complexes formed immediately after dosing with the $\mathrm{Al}^{3+}$ solution and acted as intermediates for the formation of insoluble $\mathrm{Al}-\mathrm{F}$ precipitates to remove fluoride thereafter. In the adsorption system, fluoride first adsorbed onto the AlOxHy surfaces through the hydroxyl replacement mechanism and electrostatic interaction as discussed in our previous study [19]. Additionally, the adsorption of fluoride also contributed to the dissolution of AlOxHy and the formation of Al-F complexes; this effect will be discussed in detail later. Al-F complexes may also remove fluoride by transforming to $\mathrm{F}-\mathrm{Al}-\mathrm{OH}$ precipitates. However, this effect was less significant than direct adsorption in removing fluoride.

\subsection{Effects of fluoride on species transformation of $A l$}

\subsubsection{Effect of fluoride on $\mathrm{Al}^{3+}$ hydrolysis and the formation of Al-based precipitates}

To illustrate the effect of fluoride on the hydrolysis of $\mathrm{Al}^{3+}$, the equilibrium $\mathrm{pH}$ was continuously measured during slow titration of $\mathrm{NaOH}$ solution $(1 \mathrm{~mol} / \mathrm{L})$ into $\mathrm{Al}^{3+}$ solutions $(40 \mathrm{mg} / \mathrm{L})$ with different fluoride concentrations, i.e., $4.4,16.3$, and $31.6 \mathrm{mg} / \mathrm{L}$; the results are indicated in Fig. 4. The groundwater used in this experiment contained the co-existing ions silicate, phosphate, and carbonate at the concentrations of $0.18,0.001$, and $0.017 \mathrm{mmol} / \mathrm{L}$, respectively. MINTEQ modeling indicated that these anions showed little effect on the consumption of $\mathrm{OH}^{-}$by $\mathrm{Al}$ ions (Fig. S6).

It can be observed in Fig. 4 that equilibrium $\mathrm{pH}$ gradually increased with continuous addition of $\mathrm{NaOH}$ solution, and the most

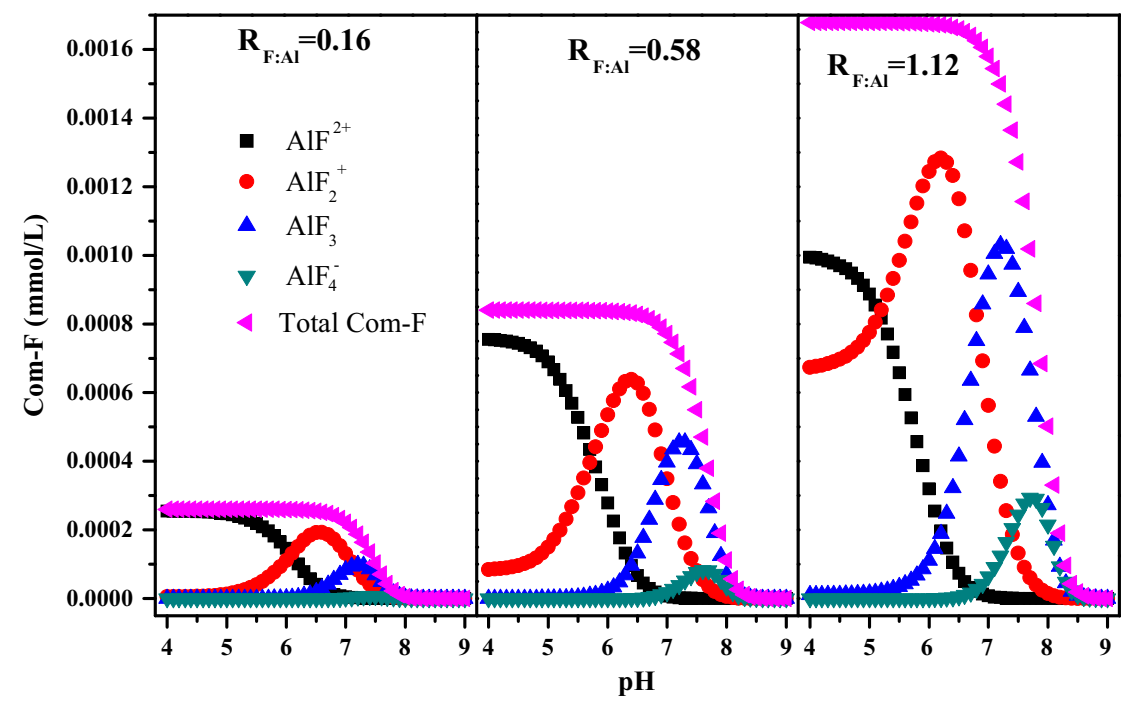

Fig. 6. Species distribution of Com-F over wide $\mathrm{pH}$ ranges from 4.0 to 9.0 . (Experimental conditions: doses of $\mathrm{Al}=40 \mathrm{mg} / \mathrm{L},[\mathrm{F}]_{0}=4.4,16.3$ and $31.6 \mathrm{mg} / \mathrm{L}$ ). 
significant $\mathrm{pH}$ increase appeared in the $\mathrm{pH}$ range from 5.5 to 7.0. At higher $\left[\mathrm{F}^{-}\right]_{0}$, a lower amount of $\mathrm{NaOH}$ solution was required to achieve the same equilibrium $\mathrm{pH}$. For example, the volume of $\mathrm{NaOH}$ consumed was determined to be 3400,2800 and $2100 \mu \mathrm{L}$ at $[\mathrm{F}]_{0}$ of $4.4,16.3$ and $31.6 \mathrm{mg} / \mathrm{L}$ to achieve an equilibrium $\mathrm{pH}$ of 5.5. Fluoride can also participate in the hydrolysis of $\mathrm{Al}^{3+}$, and the formation of insoluble precipitates of $\mathrm{AlF}_{2}(\mathrm{OH}), \operatorname{AlF}(\mathrm{OH})_{2}$, and $\mathrm{AlF}_{3}$ as well as $\mathrm{Al}(\mathrm{OH})_{3}$ has been reported before, as indicated in Eqs. (3)-(5) [9]. Fluoride reduced the amount of $\mathrm{NaOH}$ required to achieve the formation of insoluble Al-based precipitates (e.g., $\mathrm{Al}(\mathrm{OH})_{3}, \mathrm{Al}-\mathrm{OH}-\mathrm{F}$, and $\mathrm{Al}-\mathrm{F}-\mathrm{OH}$ precipitates) in the abovementioned $\mathrm{pH}$ ranges from 5.5 to 7.0. Further increase in $\mathrm{pH}$ contributed to the dissolution of Al-based precipitates into aluminates. The interaction between fluoride and aluminates was slight, and the $\mathrm{NaOH}$ volumes required to achieve the high $\mathrm{pH}$ of 9 were observed to be independent of the $\left[\mathrm{F}^{-}\right]_{0}$ levels.

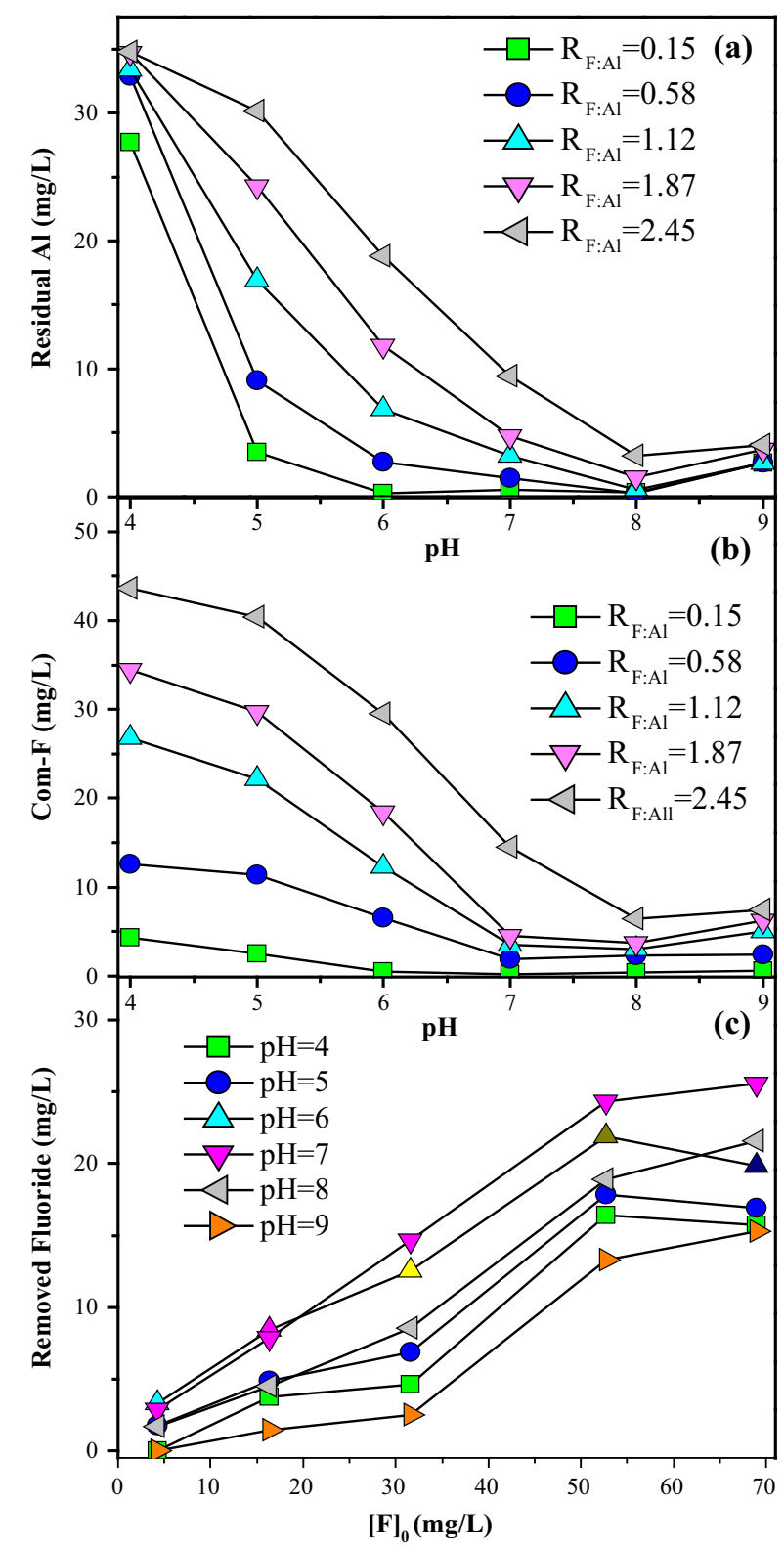

Fig. 7. Effect of initial fluoride concentrations on (a) Al dissolution, (b) Comp-F, and (c) fluoride removal after AlOxHy adsorption. (Experimental conditions: dose of $\mathrm{AlOxHy}=40 \mathrm{mg} / \mathrm{L}$ as $\left.\mathrm{Al},[\mathrm{F}]_{0}=4.3-69 \mathrm{mg} / \mathrm{L}\right)$.
$\mathrm{AlF}_{2}^{+}+\mathrm{OH}^{-} \rightarrow \mathrm{AlF}_{2}(\mathrm{OH})$

$\mathrm{AlF}(\mathrm{OH})^{+}+\mathrm{OH}^{-} \rightarrow \mathrm{AlF}(\mathrm{OH})_{2}$

$\mathrm{AlF}^{2+}+2 \mathrm{OH}^{-} \rightarrow \mathrm{AlF}(\mathrm{OH})_{2}$

The corresponding concentrations of Com-F, Free-F, and Com-Al were further quantified by the visual MINTEQ software (Fig. 5). Interestingly, it was observed that Com-F showed little variation, whereas Com-Al decreased with increasing $\mathrm{pH}$ from 4 to 7 , and this indicated the dissociation of Com-Al. At the expense of the lowered content of Com-Al, the ratios of $\mathrm{R}_{\mathrm{F}: \mathrm{Al}}$ within $\mathrm{Al}-\mathrm{F}$ complexes increased accordingly (Fig. 6). These species transformations of fluoride and $\mathrm{Al}$ achieved constant concentrations of Com-F in the $\mathrm{pH}$ range 4-7, and favored the formation of insoluble $\mathrm{Al}-\mathrm{F}-\mathrm{OH}$ precipitates. This effect contributed to the consumption of less $\mathrm{OH}^{-}$for the precipitation of $\mathrm{Al}$ ions and to the observed lower amount of $\mathrm{OH}^{-}$required to achieve the same $\mathrm{pH}$ at elevated $[\mathrm{F}]_{0}$. At $\mathrm{pH}$ above 7.0, the dissociation of Com-F to Free-F and the dissolution of Al-based precipitates occurred, and the removal of fluoride was inhibited thereafter. The formation of Al-F complexes was inferred to play an important role in the removal of fluoride by $\mathrm{Al}$ coagulation.

\subsubsection{Effect of fluoride on the dissolution of AlOxHy}

AlOxHy removes Total-F by transforming Free-F to insoluble fluoride. The adsorption of fluoride also shows an effect on the transformation of $\mathrm{Al}$ species and the removal of fluoride thereafter. Fig. 7a illustrates the effect of fluoride at initial concentrations ([ $\left.\mathrm{F}^{-}\right]_{0}$ ) increasing from 4.3 to $69 \mathrm{mg} / \mathrm{L}$ on the dissolution of the AlOxHy, as indicated by the soluble Al concentration, over a wide equilibrium $\mathrm{pH}$ range from 4 to 9 . The dose of AlOxHy was $40 \mathrm{mg} / \mathrm{L}$ as Al. At a given $\left[\mathrm{F}^{-}\right]_{0}$, the level of soluble $\mathrm{Al}$ was observed to decrease with increasing $\mathrm{pH}$ from 4 to 8 , and then slightly increased at $\mathrm{pH} 9$. Additionally, fluoride favored the dissolution of AlOxHy into soluble $\mathrm{Al}$ over a wide $\mathrm{pH}$ range from 4 to 9 , and more significant dissolution was observed at elevated $\left[\mathrm{F}^{-}\right]_{0}$. This effect was slight at low $\mathrm{R}_{\mathrm{F}: \mathrm{Al}}(\leqslant 1.2: 1)$ for $\mathrm{pH} 8-9$. At $\mathrm{pH}$ below 7.0, the released $\mathrm{Al}^{3+}$ tended to form $\mathrm{Al}-\mathrm{F}$ complexes with Free-F as expressed in Eq. (6). The consumption of $\mathrm{Al}^{3+}$ leads to the continuous dissolution of AlOxHy into soluble $\mathrm{Al}$ (Eq. (6)) and the formation of Al-F complexes thereafter. Additionally, fluoride can also directly form Al-F complexes with AlOxHy (Eq. (7)). The Com-F were observed to be the dominant fluoride species (Fig. 7b), and this was in accordance with a previous study [9]. At elevated $\left[\mathrm{F}^{-}\right]_{0}$, i.e., higher molar ratios of fluoride to $\mathrm{Al}\left(\mathrm{R}_{\mathrm{F}: \mathrm{Al}}\right)$, more significant dissolution of AlOxHy was observed. In basic conditions at $\mathrm{pH}$ 8 and 9, the levels of Com-F were much lower, at 6.4 and $7.5 \mathrm{mg} / \mathrm{L}$,

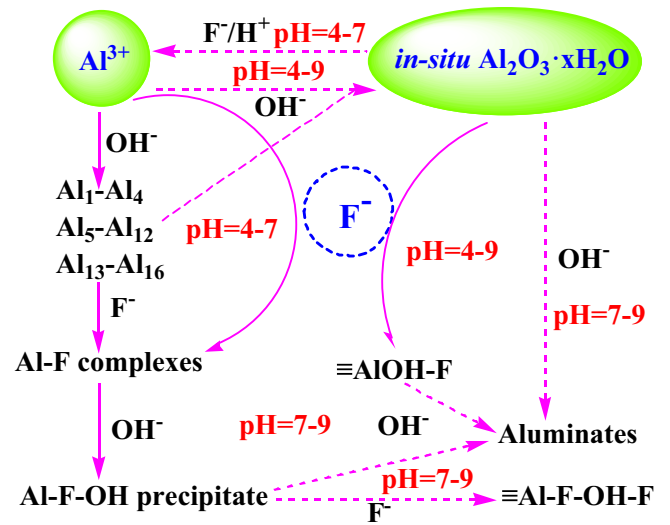

Fig. 8. Proposed dominant reactions involved in the removal of fluoride by $\mathrm{Al}$ coagulation and adsorption. 


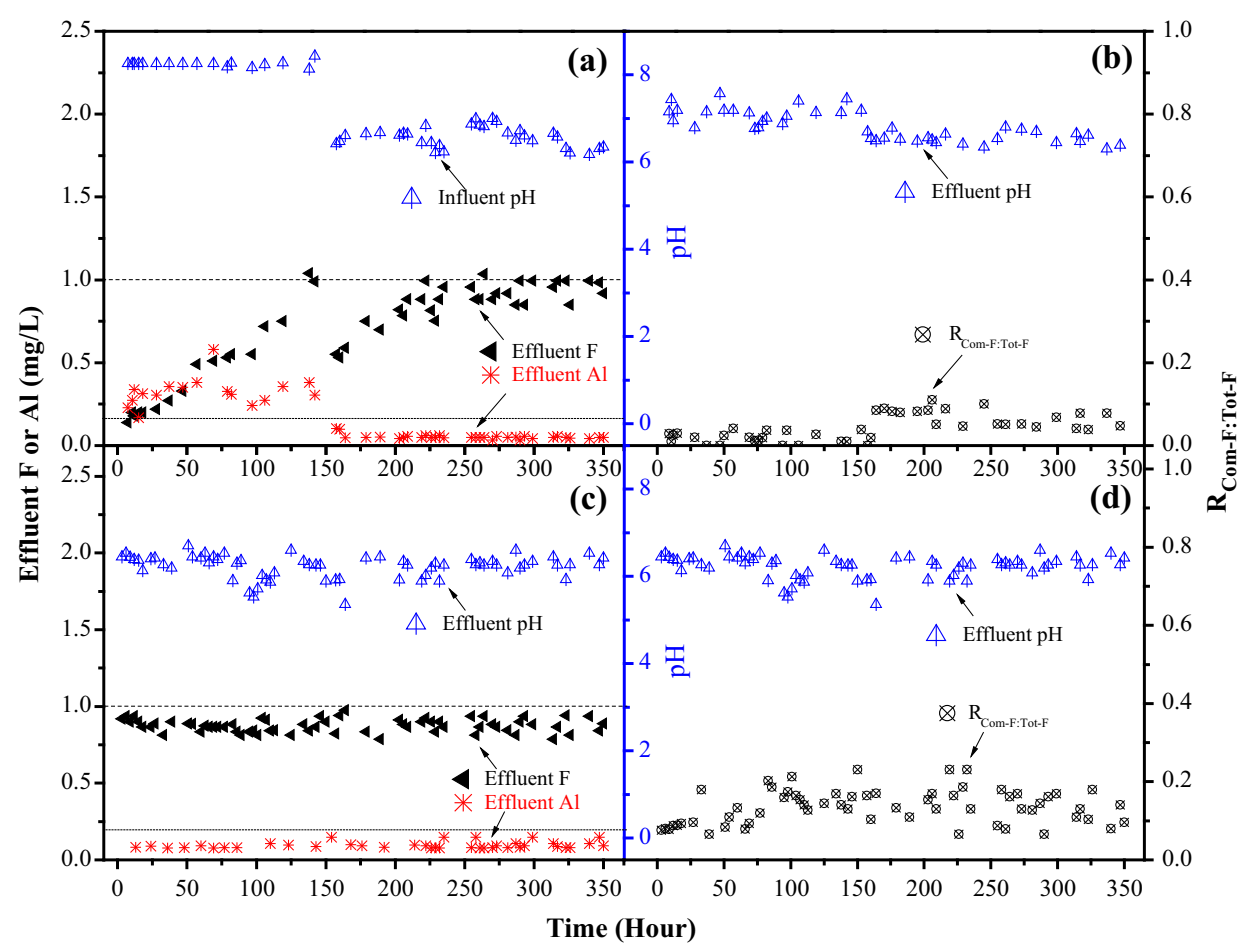

Fig. 9. The variation of $\mathrm{pH}, \mathrm{F}, \mathrm{Al}$, and $\mathrm{R}_{\mathrm{Com}-\mathrm{F}: \mathrm{Tot}-\mathrm{F}}$ in the AlOxHy adsorption system (a and b) and the Al coagulation system (c and d) in pilot-scale continuous method.

even at extremely high $\mathrm{R}_{\mathrm{F}: \mathrm{Al}}$ of $2.45: 1$, and the corresponding Free-F concentrations were determined to be 41.6 and $46.8 \mathrm{mg} / \mathrm{L}$. At $\mathrm{pH} \geqslant 8$, soluble $\mathrm{Al}$ mainly exists as aluminates rather than $\mathrm{Al}^{3+}$ ions. Interactions between soluble aluminates and Free-F rarely occurred, and fluoride showed much less effect on Al dissolution, except at extremely high $\mathrm{R}_{\mathrm{F}: \mathrm{Al}}$ (Fig. 7b).

$\mathrm{Al}(\mathrm{OH})_{3} \rightleftarrows \mathrm{Al}^{3+}+n \mathrm{~F}^{-}+m \mathrm{OH}^{-} \rightarrow \mathrm{AlF}_{n}(\mathrm{OH})_{m}^{(3-n-m)+}$

$\mathrm{Al}(\mathrm{OH})_{3}+n \mathrm{~F}^{-} \rightarrow \mathrm{AlF}_{n}^{(3-n)+}+3 \mathrm{OH}^{-}$

These effects also had an influence on the removal of fluoride by AlOxHy (Fig. 7c). Generally, the removed fluoride increased with elevated $\left[\mathrm{F}^{-}\right]_{0}$ over a wide $\mathrm{pH}$ range from 4 to 9 , owing to the higher concentration gradient between fluoride and AlOxHy, and the maximum removal of fluoride was observed at weakly acidic and neutral $\mathrm{pH}$ of 6 and 7; this was consistent with results in Fig. 3. However, at extremely high $\left[\mathrm{F}^{-}\right]_{0}$ of $69 \mathrm{mg} / \mathrm{L}$ (i.e., $\mathrm{R}_{\mathrm{F}: \mathrm{Al}}=2.45: 1$ ), the removed fluoride decreased slightly in the range $\mathrm{pH}$ 4-6 rather than increasing with elevated $\left[\mathrm{F}^{-}\right]_{0}$, as observed in $\mathrm{pH}$ 7-9. This may be attributed to the more significant effect of fluoride on AlOxHy dissolution at low $\mathrm{pH}$ than that in high $\mathrm{pH}$ ranges. Generally, the formation of Al-F complexes was favored under acidic conditions and elevated $\left[\mathrm{F}^{-}\right]_{0}$. This effect facilitated the AlOxHy dissolution and decreased the amount of Al available for fluoride removal thereafter. However, at pH 7-9, Al fluoride complex formation was slight, and the extent of Al-F complexation (Fig. 7b) and AlOxHy dissolution (Fig. 7a) also were slight relative to that at $\mathrm{pH} 4-6$. In the $\mathrm{pH}$ range 7-9, fluoride removal was mainly attributed to its adsorption onto the surface of AlOxHy. The extent of AlOxHy dissolution was slight even at high $\mathrm{R}_{\mathrm{F}: \mathrm{Al}}$ of 2.45:1, and the adverse effect of fluoride concentration on fluoride removal was insignificant thereafter.

The enhanced dissolution of AlOxHy favored the formation of $\mathrm{Al}-\mathrm{F}$ complexes, as indicated by the increased Com-F concentrations at elevated $[\mathrm{F}]_{0}$ over a wide $\mathrm{pH}$ range from 4 to 9 (Fig. $7 \mathrm{~b}$ ). It was noted that Com-F was detected at high $\mathrm{pH}$ of 8 and 9, although the ratios of Com-F to total-F were as low as $0.15: 1$ or less. This was unexpected, that Com-F could exist under alkaline conditions. This result inferred that fluoride at higher $\mathrm{R}_{\mathrm{F}: \mathrm{Al}}$ also would lead to the dissolution of AlOxHy even under alkaline conditions and inhibit fluoride removal afterward, and the exact species involved should be characterized in future study.

\subsection{Dominant reactions involved in the removal of fluoride by coagulation and adsorption}

On the basis of the abovementioned results, the dominant reactions involved in the removal of fluoride by $\mathrm{Al}^{3+}$ coagulation and AlOxHy adsorption are illustrated in Fig. 8. In the $\mathrm{Al}^{3+}$ coagulation system, $\mathrm{Al}^{3+}$ hydrolysis and the formation of $\mathrm{Al}-\mathrm{F}$ complexes occur immediately after dosing $\mathrm{Al}^{3+}$ into fluoride-containing water. Al-F complex formation is favored at low $\mathrm{pH}$, whereas the extent of $\mathrm{Al}^{3+}$ hydrolysis increases with elevated $\mathrm{pH}$. Insufficient $\mathrm{Al}^{3+}$ hydrolysis at $\mathrm{pH} 4-6$ contributes to $\mathrm{Al}^{3+}$ polymerization and to the formation of $\mathrm{Al}$ polymers, i.e., $\mathrm{Al}_{2}-\mathrm{Al}_{4}, \mathrm{Al}_{5}-\mathrm{Al}_{12}$, and $\mathrm{Al}_{13}-\mathrm{Al}_{16}$ [23,24]. These $\mathrm{Al}$ polymers can also react with fluoride to form $\mathrm{Al}-\mathrm{F}$ complexes, as indicated by ESI-MS analysis (Fig. S7, Fig. S8, and Table S2). At elevated $\mathrm{pH}$, these $\mathrm{Al}$ polymers can either transform to amorphous $\mathrm{Al}(\mathrm{OH})_{3}$ or precipitate as insoluble $\mathrm{Al}-\mathrm{F}-\mathrm{OH}$, both of which can further adsorb fluoride. Moreover, the amorphous $\mathrm{Al}(\mathrm{OH})_{3}$ formed in-situ can achieve fluoride removal via an adsorption mechanism to form Al-OH-F. Additionally, the Al-F complexes at different $\mathrm{R}_{\mathrm{F}: \mathrm{Al}}$ can transform to insoluble $\mathrm{Al}-\mathrm{F}-\mathrm{OH}$ with increased $\mathrm{pH}$. At further elevated $\mathrm{pH}$, the dissolution of $\mathrm{Al}(\mathrm{OH})_{3}, \mathrm{Al}-\mathrm{F}-\mathrm{OH}$, and $\mathrm{Al}-\mathrm{OH}-$ $\mathrm{F}$ into aluminates occurs.

In the AlOxHy adsorption system, the replacement of surface hydroxyl groups by fluoride, i.e., the formation of $\mathrm{Al}-\mathrm{OH}-\mathrm{F}$, contributes to the removal of fluoride [12]. The dissolution of AlOxHy occurs even in the absence of fluoride, and more significant dissolution occurs at $\mathrm{pH}<6$ and $\mathrm{pH}>8$ [12]. The presence of fluoride facilitates the dissolution of AlOxHy, especially in the low $\mathrm{pH}$ range (Fig. 7a). The released $\mathrm{Al}^{3+}$ from AlOxHy dissolution follows the above-noted pathways of species transformation. The dominant reactions between $\mathrm{Al}$ and fluoride species are highly 
dependent on equilibrium $\mathrm{pH}$ and $\mathrm{R}_{\mathrm{F}: \mathrm{Al}}$, and impact the removal of fluoride by these two processes.

\subsection{Fluoride removal by coagulation and adsorption in pilot-scale continuous experiments}

Fig. 9 illustrates the fluoride removal of the coagulation and adsorption processes in the pilot-scale system. $[\mathrm{F}]_{0}$ was in the range from 3.3 to $4.4 \mathrm{mg} / \mathrm{L}$, whereas $\mathrm{pH}$ ranged from 6.2 to 8.4 . In the adsorption process, residual fluoride increased rapidly and exceeded the MCL of fluoride as issued by the National Drinking Water Standard, i.e., $1 \mathrm{mg} / \mathrm{L}$, after a run length of $150 \mathrm{~h}$. This corresponded to 150 bed volumes (BVs). By decreasing influent $\mathrm{pH}$ from 8.4 to 7.0 and 6.2 , the levels of residual fluoride were kept below $1 \mathrm{mg} / \mathrm{L}$ for run lengths from $150 \mathrm{~h}$ to $353 \mathrm{~h}$. The equilibrium adsorption capacity of the AlOxHy was calculated to be $25.1 \mathrm{mg} / \mathrm{g}$ as Al with respect to the equilibrium fluoride concentration of $1 \mathrm{mg} / \mathrm{L}$ (Table S3). By comparison, residual fluoride was found to be consistently below $1 \mathrm{mg} / \mathrm{L}$ in the coagulation process at an $\mathrm{Al}$ dose of $35 \mathrm{mg} / \mathrm{L}$ throughout the 350-h run length. Although nitric acid solution was not added, the hydrolysis of $\mathrm{Al}$ decreased effluent $\mathrm{pH}$ to the optimum $\mathrm{pH}$ range of near 6.5. Additionally, the precipitation of Al-F complexes was also favored and the removal of fluoride was increased greatly (Fig. 3). It is noted that a small amount of colloid particles inevitably existed in the groundwater, although the turbidity was as low as 0.3 NTU. In this case, the sweep coagulation mechanism was also involved in removal of fluoride, considering the extremely high Al dose of $35 \mathrm{mg} / \mathrm{L}$ at pH 6.5, as indicated by the design and operation diagram of aluminum coagulation [25]. The equilibrium adsorption capacity for equilibrium $\mathrm{F}$ below $1 \mathrm{mg} / \mathrm{L}$, as expressed by the total removed fluoride divided by the total dosed Al coagulant, was determined to be $85.2 \mathrm{mg} / \mathrm{g}$ as $\mathrm{Al}$.

Besides the pH-decreasing effect, the remarkable superiority of Al coagulation over AlOxHy adsorption may be attributed to the involvement of $\mathrm{Al}-\mathrm{F}$ complex formation and $\mathrm{Al}-\mathrm{F}-\mathrm{OH}$ precipitation. In the adsorption system, the ratios of Com-F to Total-F $\left(\mathrm{R}_{\text {Com-F:Tot-F}}\right)$ were below $0.04: 1$ and in the range from $0.04: 1$ to $0.11: 1$ in the effluent $\mathrm{pH}$ ranges of $8.2-8.4$ and $6.2-7.0$, respectively (Fig. 9b). The effluents in the coagulation system showed

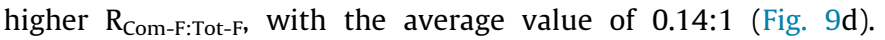
Interestingly, elevated $\mathrm{R}_{\mathrm{Com}-\mathrm{F} \text { :Tot-F }}$ decreased rather than increased residual Al levels, which were continuously below the Al MCL $(0.2 \mathrm{mg} / \mathrm{L})$. In the adsorption system, residual Al concentrations were above $0.2 \mathrm{mg} / \mathrm{L}$ throughout the 150 -h run length, owing to the dissolution of AlOxHy. After adjusting influent $\mathrm{pH}$ to below 7.0, residual Al decreased to below $0.2 \mathrm{mg} / \mathrm{L}$.

\section{Conclusions}

(1) Al coagulation shows higher removal efficiency toward fluoride than AlOxHy adsorption, not only at the same $\mathrm{pH}$ but also the same $\mathrm{Al}$ dose, and Al-F complexation plays a determining role in removing fluoride for both $\mathrm{Al}$ coagulation and AlOxHy adsorption.

(2) Fluoride favors the transformation of $\mathrm{Al}^{3+}$ and $\mathrm{Al}-\mathrm{F}$ complexes to insoluble $\mathrm{Al}-\mathrm{F}-\mathrm{OH}$, and fluoride removal by coagulation is improved thereafter. However, Al-F complexation adversely inhibits the adsorption of fluoride onto AlOxHy, especially at excessive fluoride concentrations.

(3) The pilot-scale field experiment demonstrates that Al coagulation shows superior fluoride removal compared to AlOxHy adsorption, and a higher $\mathrm{R}_{\text {Com-F:Tot-F }}$ is observed in the coagulation system than in the AlOxHy adsorption system.

\section{Acknowledgements}

This work was supported by the National Natural Science Foundation of China (Grant Nos. 21177143 and 21177144) and the National Science Foundation for Distinguished Young Scholars of China (Grant No. 51225805).

\section{Appendix A. Supplementary material}

Supplementary data associated with this article can be found, in the online version, at http://dx.doi.org/10.1016/j.seppur.2015.05. 005.

\section{References}

[1] C.Y. Hu, S.L. Lo, W.H. Kuan, Effects of the molar ration of hydroxide and fluoride to $\mathrm{Al}(\mathrm{III})$ on fluoride removal by coagulation and electrocoagulation, J. Colloid Interface Sci. 283 (2005) 472-476.

[2] A.M. Raichur, M.J. Basu, Adsorption of fluoride onto mixed rare earth oxides, Sep. Purif. Technol. 24 (2001) 121-127.

[3] A. Tor, Removal of fluoride from an aqueous solution by using montmorillonite, Desalination 201 (2006) 267-276.

[4] C. Castel, M. Schweitzer, M.O. Simonnot, M. Sardin, Selective removal of fluoride ions by a two-way ion-exchange cyclic process, Chem. Eng. Sci. 55 (2000) 3341-3352.

[5] M.F. Chang, J.C. Liu, Precipitation removal of fluoride from semiconductor waste-water, J. Environ. Eng. 133 (2007) 419-425.

[6] S. Chakrabortty, M. Roy, P. Pal, Removal of fluoride from contaminated groundwater by cross flow nanofiltration: transport modeling and economic evaluation, Desalination 313 (2013) 115-124.

[7] J.H. Lu, W.P. Liu, W. Zheng, The removal mechanisms of fluoride ion by Al salt coagulant, Acta Sci. Circum. 20 (2000) 709-713.

[8] F. Shen, X. Chen, P. Gao, G. Chen, Electrochemical removal of fluoride ions from industrial wastewater, Chem. Eng. Sci. 58 (2003) 987-993.

[9] W.X. Gong, J.H. Qu, R.P. Liu, H.C. Lan, Effect of aluminum fluoride complexation of fluoride removal by coagulation, Colloid Surf. A-Physicochem. Eng. Aspects 395 (2012) 88-93.

[10] H.Z. Zhao, W. Yang, J. Zhu, J.R. Ni, Defluoridation of drinking water by combined electrocoagulation: effects of the molar ratio of alkalinity and fluoride to Al(III), Chemosphere 74 (2009) 1391-1395.

[11] F. Shen, X.M. Chen, P. Gao, G.H. Chen, Electrochemical removal of fluoride ions from industrial wastewater, Chem. Eng. Sci. 58 (2003) 987-993.

[12] R.P. Liu, L.J. Zhu, W.X. Gong, H.C. Lan, H.J. Liu, J.H. Ou, Effects of fluoride on coagulation performance of aluminum chloride towards Kaolin suspension, Colloid Surf. A-Physicochem. Eng. Aspects 421 (2013) 84-90.

[13] B. Amit, K. Eva, S. Mika, Fluoride removal from water by adsorption - a review, Chem. Eng. J. 171 (2011) 811-840.

[14] F.F. Chang, J.H. Qu, H.J. Liu, R.P. Liu, Xu Zhao, Fe-Mn binary oxide incorporated into diatomite as an adsorbent for arsenite removal: preparation and evaluation, J. Colloid Interface Sci. 338 (2009) 353-358.

[15] Y. Ku, H.M. Chiou, The adsorption of fluoride ion from aqueous solution by activated alumina, Water Air Soil Pollut. 133 (2002) 349-360.

[16] S.G. Wang, Y. Ma, Y.J. Shi, W.X. Gong, Defluoridation performance and mechanism of nano-scale aluminum oxide hydroxide in aqueous solution, J. Chem. Technol. Biotechnol. 84 (2009) 1043-1050.

[17] V. Tomar, S. Prasad, D. Kumar, Adsorptive removal of fluoride from water samples using Zr-Mn composite material, Microchem. J. 111 (2013) 116-124.

[18] S.K. Das, S. Kapoor, H. Yamada, A.J. Bhattacharyya, Effects of surface acidity and pore size of mesoporous alumina on degree of loading and controlled release of ibuprofen, Micropor. Mesopor. Mater. 118 (2009) 67-272.

[19] R.P. Liu, W.X. Gong, H.C. Lan, Y.P. Gao, H.J. Liu, J.H. Qu, Defluoridation by freshly prepared aluminum hydroxides, Chem. Eng. J. 175 (2011) 144-149.

[20] H.J. Liu, J.H. Qu, C.Z. Hu, Characteristics of nanosized polyaluminum chloride coagulant prepared by electrolysis process, Colloid Surf. A-Physicochem. Eng. Aspects 216 (2003) 139-147.

[21] H.X. Tang, Coagulation Mechanisms of Inorganic Polymer Coagulants, Architecture and Building Press, Beijing, China, 2006. pp. 47-49.

[22] S. Hiradate, N. Yamaguchi, Chemical species of Al reacting with soil humic acids, J. Inorg. Biochem. 97 (2003) 26-31.

[23] H. Zhao, H.J. Liu, J.H. Qu, Effect of $\mathrm{pH}$ on the aluminum salts hydrolysis during coagulation process formation and decomposition of polymeric aluminum, J. Colloid Interface Sci. 330 (2009) 105-112.

[24] C.Z. Hu, H.J. Liu, J.H. Qu, D.S. Wang, J. Ru, Coagulation behavior of aluminum salts in eutrophic water significance of $\mathrm{Al}_{13}$ species and $\mathrm{pH}$ control, Environ. Sci. Technol. 40 (2006) 325-331.

[25] A. Amirtharajah, K.M. Mills, Rapid-mix design for mechanism of alum coagulation, J. AWWA 74 (1982) 210-216. 